\title{
Some Aspects of the Juvenile Delinquency in Albania
}

\author{
Bledar Mustafaraj \\ Public Prosecutor, Public Prosecutor's Office of Elbasan Judicial District, Albania, \\ PhD Candidate, European University of Tirana, Albania \\ bledi_mustafaraj@hotmail.it
}

\section{Doi:10.5901/ajis.2015.v4n1s2p105}

\section{Abstract}

The phenomenon of the juvenile delinquency in the Republic of Albania, likewise the other countries of the world, has been persisting and evolving induced by a variety of factors featuring both the individuals and the society, in the objective circumstances of which minors create their own personalities. Minors are human beings in a growing and developing process characterized by certain crossroads leading them to the age of maturity. The respective society circumstances and its many problems have an obvious effect into the delicate process of minors' growth and development. It is for this reason that understanding everything regarding the "minor" problem requires both technical cognition and human skills. The behavioral negative aspects drawing people's attention can generally be observed more in youth rather than in the adult ages. Moreover, it would be better considering the present-day juvenile delinquency as the tomorrow's adult criminality. The aim of this study is to consider juvenile delinquency as a concept, theoretically, summarized and as a phenomenon having its own specific causes, alongside understanding the infant delinquent's figure and personality. By means of the statistical data, it is possible to reveal the most consumed penal acts committed by minors in the Republic of Albania. This work will be introduced according to the following structure; Understanding juvenile delinquency and its distinctions from other similar concepts; The profile of juvenile delinquents; Volume and types of the penal acts committed by minors in Albania; Juvenile delinquency in terms of gender; Recommendations concerning the juvenile delinquency problems in the Albanian state.

Keywords: Juvenile delinquency, minors, delinquents, age, criminal profile, criminal factors, delinquency structures.

\section{Introduction}

There is no doubt that criminality is one of the most obvious social phenomena exacerbating the actual society as well as one of the most treated criminological problems by since the XIX century and on. The problems relating the individuals' negative conducts attracting the attention of the society can, generally, be better observed in minors rather than in major adults. Moreover, it is important to treat the present-day minors' criminality as a potential criminality of the major adults in the future.

Minors' criminality is a worldwide phenomenon, persisting both in big and industrialized cities and in the less developed areas, in rich and high-class families and in the poorest ones; therefore, it is a phenomenon featuring all the social strata, devoid of exception ${ }^{1}$.

In this point of view, in the Republic of Albania as well, the phenomenon of juvenile delinquency has been persisting in the same ways as in the other countries of the world, induced by a variety of factors linked both with the individual as well as with the society and with the objective circumstances in which minors are grown and brought up and in which build up their personalities. The aim of this study is to deal with the following issues:

- Understanding juvenile delinquency and its distinctions from other similar concepts;

- The profile of juvenile delinquents;

- Volume and types of the penal acts committed by minors in Albania;

- Juvenile delinquency in terms of gender;

- Recommendations concerning the juvenile delinquency problems in the Albanian state. 


\section{Understanding Juvenile Delinquency and Its Distinctions from Other Similar Concepts}

It is somewhat difficult to define what juvenile delinquency means per se. In some countries juvenile delinquency is qualified as a such basing on the definitions made by the Penal Code regarding law infringements/violations committed by minors, whereas in other countries juvenile delinquency is addressed by a series of criminal offenses foreseen in their basic laws. It is for this reason that statistical data provided by some countries regarding juvenile delinquency, are inflated, whereas in some other countries data are not reflected exactly, but a limited number of deviant conducts2. Prior to dealing with juvenile delinquency, it is mandatory to clarify the concepts "delinquency" and "juvenile"3.

At first place, delinquency or criminality in general, was considered as a specific phenomenon of deviation or inconsistency4. In this point of view and according to the perception: "criminality is the attitude resulting from the individuals' failure to adapt to the rules of the society they live in5" - a definition which says much and nothing at the same time. This is because there is no clue if it refers to the rules as a whole or to a part of them and if people, majors or minors, have to adapt to rules of a certain society.

Because of the influences by the classical school of the psycho-biological Penal Law and positivism, the juvenile delinquency has usually been considered as a totally individual issue; actually, the greatest part of the criminologists assert that criminality is a phenomenon featuring any kind of society and reflecting their main characteristics so that, to understand criminality as a phenomenon it is necessary to realize the main bases of each social class, both its functional and non-functional bases.

Amendments made in the field of legal punishment, especially in the field of trafficking crimes, in the economic domain and in the field of offences to environment, result to favor the thesis asserting the cultural dependence of the criminal offences, as maintained by Hegel in 1821. Nevertheless, to whatever extent this hypothesis is true, it is necessary to be concretized since it does not explain why and to what direction the concept of the criminal offences change in a certain epoch and moreover, it does not explain the reasons behind the variety of forms the deplorable acts are displayed within the same cultural circle6. However, according to Kaiser, it should be kept in mind that the conduct being subjected to social punishment in a certain country may not be considered as a criminal offence in other countries7. Considering these ideas Herrero Herrero defines criminality as a social phenomenon consisting of the entirety of infringements directed against the base rules of coexistence and occurring in a certain time and place 8. Another author, López Rey, considers criminality as an individual and social-political phenomenon featuring the society as a whole and whose prevention, control and treatment requires the need for community collaboration and an adequate sentencing system.9.

Once we have considered "criminality" as a concept "juvenile" needs also to be perceived, namely, what "juvenile delinquency' stands for? The concept will not be seen in a wider meaning but in terms of penal sciences, perceiving it as crimes committed by individuals who have not reached major age10. It should be born in mind that, in various states, in its penal meaning, major age does not often coincide with civil and political meaning of it as such11. According to Herrero Herrero, juvenile delinquency is more a social-historical concept12. In this line of reasoning Garrido Genovés defines juvenile delinquency as a cultural figure since its definition and the legal treatment depends on various factors, in different states, reflecting an entirety of psychological and legal concepts. Technically, the juvenile delinquent is an individual not yet in major age, in terms of the judicial-penal meaning and who commits an action which is punishable by the law 13.

2David, P.R.: "Sociología criminal juvenil", Depalma, Buenos Aires, 1979, p. 31.

3Herrero Herrero, C.: "Criminología (parte general y especial)", Dykinson, Madrid, 1997, p. 359. Also, Siegel, L. J, Welsh B. C.: "Juvenile delinquency. Theory, Practise and Law", 11th edition, Wadsworth, Cengage Learning, 2009, 2012, p. 9-13.

4/zquierdo Moreno, C.: "Delincuencia juvenil en la sociedad de consumo", Mensajero, Bilbao, 1980, p. 7.

${ }^{5}$ Taken from "Report on Juvenile Delinquency, Advisory Committee", Melbourne, 1956, webpage: http://www.parliament.vic.gov.au/ vufind/Record/51816, last accessed on 15.02.2015.

6Sutherland, E. H, Cressey, D. R.: “Criminologia”, translated by Zanichetti Mario, Giuffrè Editore, Milano, 1996, p.141-144.

7Kaiser, G.: "Introducción a la criminología", Dykinson, Madrid, 1988, p. 86-87.

${ }^{8}$ Herrero Herrero, C.: "Criminología.....", works. cited., p. 225.

'López Rey, M.: "Criminología. Criminalidad y planificación de la política criminal", Madrid, 1978, p. 10-11 and 21-38.

${ }_{10}$ Herrero Herrero, C.: "Criminología.....", works. cited., p. 360.

11 Sutherland, E. H, Cressey, D. R.: "Criminologia...", works, cited, p. 27-29.

${ }^{12 H e r r e r o ~ H e r r e r o, ~ C .: ~ " C r i m i n o l o g i ́ a . . . . . ", ~ w o r k s . ~ c i t e d ., ~ p . ~} 362$.

${ }^{13}$ Garrido Genovés, V.: "Delincuencia juvenil", Alambra, Madrid, 1986, p. 11. 
According to Göppinger, in the criminology sciences, the concept juvenile should have a wider meaning, including age groups from $14-21$ years of age, who should further be divided in minors and semi-majors14. In some countries of the Western Europe where there have been studies of the juvenile delinquency, scholars make distinctions between minors and a special category, the so-called "young adults". The term stands for individuals ranging from 18 - 21 years of age and in several cases even from 23 - 25 years of age15. According to this reasoning it can be said that a juvenile delinquent 16 is the individual who has not yet reached a major age, as foreseen by the penal law and who commits an act which is punishable by the law.

The General Assembly of the United Nations has provided its own definition for the juvenile delinquent in one of its acts: "A juvenile delinquent is a child or young person who is alleged to have committed or who has been found to have committed an offence."17.

The Penal Code of the Republic of Albania, (1995), bounds the minimum age of criminal responsibility at 14 years of age for crimes and at 16 years of age for penal infringements. This determination complies with Article 1 of the Convention on the Rights of the Child asserting: "For the purposes of the present Convention, a child means every human being below the age of eighteen years unless under the law applicable to the child, majority is attained earlier".

According to the Albanian Penal Code, concerning crimes, the intellectual ability and the necessary volition for minors to be responsible is achieved at the 14 years of age. This infers that minors have reached the proper mental maturity to distinguish the illegitimate and socially hazardous character of their actions and inactions. Determination of this age limit is based on the rationale that in the actual conditions of our society's development, a minor of this age possesses the proper knowledge to understand what is or is not a crime. A minimum age limit of 16 years of age has been determined for penal infringements, reasoning that the content of an infringement is more abstract and difficult to be comprehended by minors, so they should have a higher level of noses and living experiences to be responsible18. Persons who have not yet reached 14 years old cannot not be subject to penal responsibility but they can be subject to education measures. The juvenile's age to rich mental maturity, sufficient to comprehend the gravity of the offense and to understand the implications of his conducts in the society is not often the same for different minors. By since 14 years of age, which make up the lowest age limit of minority, the minors' mental abilities evolve vehemently until reaching 18 years of age, which is considered the age when minors' intellectual development to comprehend the gravity of criminal offences has been completed. So, above this age limit, the criminological treatment of the penal offences and of the persons who have committed them, shows that the study of the juvenile delinquency should not be limited solely to cognizing juvenile criminal offences committed, the means used to perform them or their consequences, but even to determine the features of the persons who have committed them, the scale of their abilities as well as their personality 19. That is why legislation envisages limited penal responsibilities for minors. Finally, and by bearing in mind the aforementioned assertions, the juvenile delinquency in Albania can be defined as a social phenomenon incorporating the entirety of criminal offences committed by 14 - to 18 year-old individuals.

Perception of the juvenile criminality should be distinguishable from the other similar concepts, or the ones having common bases, suchlike the notion of the social conflict by means of which, according to Coser, is inferred the struggle for status, power and equal means, with parties aiming to liquidate, harm or eliminate their adversaries 20 . These concepts can bring confusion in treating the problems whose root causes are social avoidance or exclusion and anomy.

Cohen and Mertone have defined avoidance as a behavior or an attitude ceding the agreed norms established by a certain group to be applied by individuals who are transferred into active subjects of offences. Therefore, the avoidance is a result of the very ceding the individuals render to the previously established system of rules.21.

${ }^{14}$ Núñez Paz, M.A.; Alonso Pérez, F.: "Nociones de criminología", Colex, Madrid, 2002, p. 306.

${ }^{15}$ Elezi, E; Hysi, V.: "Politika Kriminale", Tiranë, 2006, p 155.

${ }^{16}$ This term, delinquent, sems to be closer to reality as compared to the term "criminal'. This is for the fact that, actually, the Albanian legislation terms as criminals those individuals who commit crimes. Meanwhile, there are minors who also commit penal infringements, so it would have been unjust if they were referred to as criminals, by using a general term for all kinds of offenders. The term "delinquent" has a general character and provides a better description of the situation

${ }^{17}$ Beijing Rules, Paragraph 2. 2, bullet c.

${ }_{18}^{18}$ Muçi,Sh.: "E drejta penale, Pjesa e Përgjithshme”, Botimet Dudaj, Tiranë, 2007, p. 127-128.

${ }^{19}$ Loeber, R., Farrington, D. P.: "From juvenile delinquency to adult crime. Criminal careers, Justice policy, and Prevention", Oxford University Press, New York, 2012, p. 4.

20Herrero Herrero, C.: "Criminología.....", works. cited., p. 363.

${ }^{21}$ Herrero Herrero, C.: "Criminología.....", works. cited., p. 365. 
Social exclusion can be defined as a psychosocial state of an individual facing insufficiency of life-sustaining resources, lacking a decent social status totally or partially as well as living in conditions that are far from the dominant level of the community life. Social exclusion cannot be confounded with criminal situations even though it often leads to the latter22.

Anomie, which in terms of etymology means 'lawless', is, in reality a specific case of deviation, where the deviant conducts originate from contexts where law does not prevail, especially in the periods of social and political transformations having no meaning of what social and legal norms are to be followed. The situation of individuals that Park qualifies as marginalized and which persist between two or more cultures differing from each other and, by alternatively applying the rules of the one or the other, can be included in anomie, as well, as in the cases of ethnic minorities, (Roma, etc.) 23

\section{Profile of Juvenile Delinquent}

There have been many efforts, in the judicial doctrine, to describe juvenile delinquents' type that would have served as a starting point for the application of efficient preventive programmes, such as education. According to scholars, there are a lot of individuals and living factors featuring juvenile delinquents that lead to the conclusion that they are flawy people and one of the flaws is the fact that they commit criminal offences. Among these factors, inclusive but not exhaustive, the following can be mentioned24:

- Impulsiveness;

- Desire to show off ;

- Lagging behind in school;

- Taking drugs;

- Law self-esteem;

- Troubled families;

- Low social class;

- Lack of affection (family warmth);

- Aggressivity;

- Lack of social conducts;

- Lack of emotional equilibrium;

- Incongruity;

- Frustration.

Basing on the specific features of personality or features of psychosocial nature, Herrero Herrero25 divides juvenile delinquents in three typological categories:

The first category includes juvenile delinquents suffering from pathological disorders especially from:

a) Juvenile delinquents due to psychopathies. This classification has the existence of one of the psychopathy forms as a reference point. With the term 'forms of psychopathy', according to Hare, will be meant the inability of the individuals bearing this illness to feel or show affection (warmth) for their kin, a problem which they use in their own advantage. These individuals have the ability to express false sincerity, making his victims believe they are innocent or they have repented deeply - all this to disguise continuing to manipulate or lie.

Because of this state, minors are unable to adapt to a certain ambiance, since because of disorders in his personality it is difficult for them to subject to the application of rules so they act against accepted norms.

22Herrero Herrero, C.: "Criminología.....", works. cited. p. 368.

${ }^{23}$ Herrero Herrero, C.: "Criminología.....", works. cited. pp. 366-367.

${ }^{24}$ Garrido Genovés, V.; Redondo Illescas, S.: "Manual de criminología aplicada", Ediciones Jurídicas Cuyo, Mendoza, 1997, pp 143-144, 149.

${ }^{25}$ Herrero Herrero, C.: "Tipologías de delitos y de delincuentes en la delincuencia juvenil actual. Perspectiva criminológica", in Actualidad Penal, $N^{0}$ 41, 2002. f. 1089-1097. Also consult Herrero Herrero C.: "Delincuencia de menores. Tratamiento criminólogico y juridico", Dykinson, Madrid, 2008, p. 105 - 122; Sutherland, E. H, Cressey, D. R.: "Criminologia", works. cited. p. 221-245 as well as the group of authors: "Lo sviluppo antisociale: dal bambino al giovane adulto. Una prospettiva evolutiva e psichiatrico-forense", Raffaello Cortina Editore, Milano, 2010, p 237-255. 
The psychopath minor is prone to accomplish anti-social actions, due to the orientation of his/her relevant psychopathies, making these actions display coldness and cruelness in terms of subjectivity.

b) Juvenile delinquents due to neurosis. Neurosis consists into a grave psychic unwellness displaying conduct disorders. It may have different origins suchlike, failures in life, frustrations, being abandoned or having lost kin, etc. In the criminological points of view, people sick with neurosis try to hide the feeling of anxiety they experience, they commit crimes in order to be subject to punishment that in return will release them from the feeling of guilt weighing on them. This definition is applicable for minors suffering from neurosis, who, however, are much less numerous than adults.

c) Juvenile delinquents due to the distorted perceptions of the reality. This includes minors who, due to their persisting psychobiological conditions, confound fantasy with the play in such a high grade that they begin to live outside the factual reality. This abnormal condition might push them to perpetrate anti-social actions.

In the second category are included minors with anomalies of non-pathological character.

a) Juvenile delinquents with anti-social disorders in their personality. This includes minors who are hyperactive, in state of irritation, often lack the feeling of guilt, lag behind in school and are less communicative or not communicative at all. One of the main causes of these disorders are the total lack of mother or her distorted figure, while not underestimating consequences from unfulfilled paternal role which, according to certain studies, growing fatherless bring forth problems which might push children to criminality. In many cases, this includes minors living on the streets, in permanent situations of abandonment, bearing feelings of anger and resentment towards the society. All these conditions have a common denominator; lack of affection, warmth and parental care. Finally, these youngsters are driven to crimes.

b) Juvenile delinquents who respond by leaving home. These minors are maltreated in their families so they abandon them. In psychological terms, these minors are weak and instead of responding to the aggression against them, they choose going away from their families - a timeless and unidentifiable departure. This is the reason why they await to be recruited by the organized crime mobs that incite them to commit certain penal offences.

In a third category, Herrero Herrero includes minors who display almost normal or close-to-normal features of their personality. They are affected by problematic situations that do not obfuscate their consciousness, their ability to make decisions and their emotional field profoundly. This category represents the greatest part of the juvenile delinquents among whom can be mentioned the following:

a) Minors committing simple acts of vandalism, etc, due to their born psychological perturbations persisting before and during their adolescence, due to the development of their body changes.

b) Minors committing small thefts or cheating to increase their values at the face of friends who show admiration for them.

c) Minors committing crimes against property or sexual inviolability simply for pleasure since it is possible for them to resist temptations.

d) Minors committing crimes to satisfy their material greed.

It should be born in mind that classification of juvenile delinquents basing on the type of mental illnesses they are suffering from does not mean that crimes are result of the inner biological problems they suffer from. Often they commit crimes while being under the effect of the instant psychotic disorders, (hallucinations, delirious ideas, illusions, etc). The overall opinion is that, one person, including minors, commits illegal deeds motivated by different reasons. Often these reasons belong to the social nature. In analyzing criminogenic factors, I think, one should consider to intertwine both the psychic and social elements.

In these terms, West, reveals that one of the many factors leading to well understanding of the delinquents' features might be the low social class they belong to, schooling deficiencies, poverty, an unreliable family ambiance, problematic neighborhoods or numerous families. To this regard, he accented that low-social-class families lived in poor communities, had a great number of children and suffered from poverty and lack of education. In other words, such factors merge and in collaboration, create a criminal situation ${ }^{26}$.

On the other side, other scholars do not support the idea that criminal conducts prevail in the poor strata of the society. They explain the great number of sentenced minors with the fact that poor classes are more exposed to penal prosecution and sentencing as compared to the middle and rich classes for the same infringements, since both the latter

${ }^{26}$ West, D.J.: "La delincuencia juvenil", Labor, Barcelona, 1957, f. 52-53. 
would be tried in a more favorable form. In this sense, Short and Nye, in a study undertaken in 1959 revealed that North American high schools youth belonging to high social classes displayed the same bad behaviors as the others. In addition, Akers, in a study realized in 1964 with over 1000 high school students in Ohio, asserted that there was no essential connection among causes of criminality and the social-economic categories ${ }^{27}$. Personally, I support the conclusions of the second current of scholars.

Regarding Albania, it results that minors committing penal offences descend from families of a lower economic and cultural level. A part of them, descend from families originating from remote regions that have been located to urban areas, divorced families, etc. Regarding the educational level, the Statistical Year-Book of the Ministry of Justice of $2013^{28}$ offers the following data:

Minors involved in crimes
\begin{tabular}{|c|c|c|}
\hline No. of the sentenced minors & With no education & With education. \\
\hline 589 & 28 & 580 \\
\hline \\
Minors involved in penal infringements \\
\hline No. of the sentenced minors & With no education & With education \\
\hline 91 & 4 & 89 \\
\hline
\end{tabular}

\section{Volume and the Types of the Penal Offences Committed by the Juvenile Delinquents}

Description of the minors' delinquent behaviors for the period we are speaking about is, undoubtedly, a crucial point of this writing since it helps us understand the Albanian juvenile delinquents' habits and actions in depth.

In order to analyze the Juvenile delinquency in Albania, we have been referred to the Statistical Year-Book of the Ministry of Justice of $2013^{29}$, according to which, statistical data regarding juvenile delinquency, compared to 2007, 2008, 2009, 2010, 2011 and 2012, reflect a considerable increase of the phenomenon.

It is to be emphasized that in $2013,87 \%$ of minors are sentenced for crimes. However, in 2013 , as compared to 2012, the number of sentenced minors has decreased by 237 minors. Bearing in mind the rapport of the total number of sentenced minors (680) and the number of minors sentenced for crimes (589), in 2013, compared to rapport of the total number of sentenced minors (883) with the number of the minors sentenced for crimes, (826) in 2012, it results that the number of minors sentenced for crimes has decreased, (from $94 \%$ in 2012 to $87 \%$ in 2013). Considering penal infringements, compared to the same year, it results that the number of sentenced minors has been increasing. Compared to the sentenced individuals in a country scale, $(8,577)$ the sentenced minors constitute only $8 \%$ of them.

A table presentation of the data about minors involved in committing penal crimes in Albania during $2013^{30}$ would reveal the following:

\begin{tabular}{|c|c|c|}
\hline Type of penal offence & Article of Penal Code & No of minors involved \\
\hline \multicolumn{3}{|l|}{ Crimes } \\
\hline Premeditated homicide & 76 & 3 \\
\hline Homicides committed in other specific circumstances & $79 / e$ & 1 \\
\hline Manslaughter & 85 & 1 \\
\hline Serious intentional injury & 88 & 11 \\
\hline Serious wounding under the conditions of hard psychic distress & $88 / a$ & 2 \\
\hline Sexual or homosexual relations/ intercourse with minors/children & $100 / 1$ & 3 \\
\hline Serious immoral acts & 108 & 2 \\
\hline Unlawful detention & $110 / 2$ & 1 \\
\hline Prostitution & 113 & 1 \\
\hline
\end{tabular}

27West, D.J.: "La delincuencia ......", works. cited on p. 56.

${ }^{28}$ Consulted on webpage: http://www.drejtesia.gov.al/al/dokumente/statistika last accessed on 15.02.2015.

${ }^{29}$ Data taken from "Vjetari statistikor. Ministria e Drejtësisë", 2011, p. 81, to the webpage: http://www.drejtesia.gov.al/al/dokumente/ statistika last accessed on 15.02.2015.

30Data taken from "Vjetari statistikor. Ministria e Drejtësisë", 2011, p. 83-84, accessed in the webpage: http://www.drejtesia.gov.al/al/ dokumente/statistika 


\begin{tabular}{|c|c|c|}
\hline Domestic violence & $130 / a$ & 2 \\
\hline Theft & $134 / 1$ & 142 \\
\hline Theft & $134 / 2$ & 319 \\
\hline Theft & $134 / 3$ & 1 \\
\hline Robbery & 139 & 16 \\
\hline Robbery with the use of weapons & 140 & 5 \\
\hline Deception/Fraud & 143 & 3 \\
\hline Destroying property & 150 & 5 \\
\hline Destroying property by fire & 151 & 1 \\
\hline Destroying power network & 156 & 1 \\
\hline Falsification of Documents & 186 & 2 \\
\hline Falsification of Identity Documents, Passports or Visas & 189 & 5 \\
\hline Documents disappearing and stealing & $192 / a$ & 3 \\
\hline Interference in the computer transmissions & $192 / \mathrm{b}$ & 2 \\
\hline Opposing the official of the public order police & $236 / 2$ & 2 \\
\hline Assault [to an official] on duty & 237 & 1 \\
\hline Illegal manufacturing and keeping military weapons and ammunition & $278 / 2$ & 12 \\
\hline Illegal manufacturing and keeping military weapons and ammunition & $278 / 4$ & 2 \\
\hline Illegally manufacturing and keeping weapons with blades & 279 & 24 \\
\hline Manufacturing and selling narcotics & 283 & 12 \\
\hline Cultivating narcotic plants & $284 / 1$ & 2 \\
\hline Laundering of proceeds of criminal offence or criminal activity & 287 & 1 \\
\hline $\begin{array}{l}\text { The appropriation of money or goods which derive from the criminal } \\
\text { offence or criminal activity }\end{array}$ & $287 / \mathrm{b}$ & 2 \\
\hline Violation of road traffic regulations & 290 & 3 \\
\hline Breach of flight rules & 299 & 1 \\
\hline Failure to report a crime & 300 & 5 \\
\hline Obstruction of justice & 301 & 1 \\
\hline False report & 305 & 7 \\
\hline Escape of the convicted from the place of detention & 323 & 1 \\
\hline \multicolumn{3}{|l|}{ Penal Infringements } \\
\hline Threat & 84 & 4 \\
\hline Non-serious intentional injury & 89 & 10 \\
\hline Other intentional harm & 90 & 3 \\
\hline Insulting & 119 & 1 \\
\hline Coercing or prohibition to cohabit or to enter into or dissolve a marriage & 130 & 4 \\
\hline Obstructing religious ceremonies & 133 & 2 \\
\hline Unlawfully cutting forests & 205 & 4 \\
\hline Opposing an official on state duty or public service & $235 / 1$ & 2 \\
\hline Opposing the official of the public order police & $236 / 1$ & 1 \\
\hline Leaving the scene of an accident & 273 & 3 \\
\hline Breach of public peace & 274 & 1 \\
\hline Wrongful intentional use of telephone calls & 275 & 4 \\
\hline Illegal manufacturing and keeping ammunition & $278 / 3$ & 1 \\
\hline Illegally manufacturing and keeping hunting and sporting rifles & 280 & 3 \\
\hline $\begin{array}{l}\text { The appropriation of money or goods which derive from the criminal } \\
\text { offence or criminal activity }\end{array}$ & $287 / \mathrm{b}$ & 1 \\
\hline Illegal production of industrial and food items/commodities & $288 / a / 1$ & 41 \\
\hline Irregular driving of vehicles & 291 & 5 \\
\hline False declarations before the judicial police officer & $305 / \mathrm{b} / 1$ & 2 \\
\hline Others & & 1 \\
\hline
\end{tabular}

It results that the greatest number of penal offences consists of both minute and bigger thefts. They comprise a special form of "micro-criminality" in which prevails the desire to appropriate personal belongings of the others or to harm other people or their property. The minors' efforts to show off and, at the same time, a pathological need to commit extreme and dangerous acts is very obvious and significant in these cases. This typology might include all the young people who are in conflict with both their parents and the society, the ones not respecting moral norms and values and who oppose 
any kind of rules. Since there is no example to be followed, young people build their personality by choosing to imitate unreal models (mostly seen in films or magazines). Prevailing of the penal offences against property makes one think that there is a connection between the increase of the juvenile delinquency and the unrestrained greed to appropriate consumer goods. On the other side, a society based totally on consumption urges youth with the need for possessing whatever the society offers as main material goods.

\section{Juvenile Delinquency in Terms of Gender}

Male delinquents are distinguished to be more numerous than females ${ }^{31}$. Female juvenile delinquency commenced to become object of study by the end of ' $60 \mathrm{~s}$, a time that coincided with movements for the freedom of women and was considered a great achievement to this regard. The following can be mentioned among the main theories about female criminality:

- Classical, biological, psychoanalytical and psychiatric theories:

- The intermediate theories with individualist outlook and social tendencies; Thomas, Pollack, Cowie.

- The social character theories, with functional features, (the theory of the role and the theory of the equal opportunities) and critical features (the theory of social control and the theory of economic dependence).

Classical theories try to explain female criminality basing on the individual features, by the biological content, (the bio-anthropological anomalies, sexual development etc.), psychoanalytical or psychiatric ones. Prevailing in these theories is the idea equalizing female criminality with the biological or psychical disorders.

In present days, these theories have no scientific base, although they have roots in certain societies as well as in some criminological studies, suchlike those of Smart, in which the criminal female is introduced as an individual with mental disease.

Development of criminology and the disregard of biological and individual factors (determinism) opened ways for the social character theories that constitute the basis of modern theories over female criminality.

The greatest support to the science of criminology, regarding the study of the female criminality, has been given by social theories with functional features as well as critical criminology.

Functional theories (mainly the theories of roles and those of equal opportunities) have mainly been committed to explicating on the increase into the female criminality as well as the new variations in committing penal offences. Critical criminology (especially the theories of the social control and the theory of economic dependence), have been committed to study the effect of social control, be it formal or informal, on the females' criminal conducts ${ }^{32}$. If needed to compare the male and female criminality, the comparison per se cannot be made without considering distinctions persisting between the two sexes ${ }^{33}$.

1. At first place, the problematic conduct of girls is shown, in general, with the same features characterizing boys of the same age.

2. Attitudes of both sexes are to the degree that can be defined as violation of rules, but not always criminal, e.g. consuming alcohol, playing truant in school classes, etc.

3. Boys, usually are prone to be organized in certain groups in which they are incited to bad conducts, whereas girls, at least in our reality, have not yet managed to do such things.

4. It has resulted, from the study of the Court decisions, that the number of males tried and sentenced is prevailing.

5. Some of the reasons why females are less prone to behave in problematic ways have to do with the psychosocial factors and the family control. Usually the girls' way of life reflects feelings of protection and rule effectuation. They are subject of strict control by their families both about how they are doing at school and about their free time, which explains the small number of juvenile females committing penal offences.

31 Siegel, L. J, Welsh B. C.: "Juvenile delinquency...", work. cited, p. 55.

${ }_{2}$ Montañés Rodríguez, J.; Bartolomé Gutiérrez, R.; Latorre Postigo, J.M.; Rechea Alberola, C.: "Delincuencia juvenil femenina y su comparación con la masculina", in the common study "Estudios de criminología II", Universidad de Castilla La Mancha, Cuenca, 1999, p. 253-256.

33Montañés Rodríguez, J.; Bartolomé Gutiérrez, R.; Latorre Postigo, J.M.; Rechea Alberola, C.: "Delincuencia juvenil .......", works, cited. p. $275-278$. 


\section{Recommendations Concerning the Juvenile Delinquency Problems}

Juvenile delinquency is a phenomenon persisting in any societies and needs to be paid a special attention.

The society's response to that phenomenon is crucial to know the minors' personality and to intervene in order to prevent minors from getting involved into crimes.

In Albania, until recently, the solutions to these problems have not been based on the principles of "an efficient penal system" but on the principles of a "tougher and more repressive system".

Treatment of delinquent juveniles in this way has come due to the lack of a separate legal system for minors in the penal legislation and due to the mis-comprehension of the juvenile delinquents figure.

Generally, the attitudes perceived until later, regarding the response to juvenile delinquents, are typically those of a "traditional" justice.

Measures foreseen by this type of system consist of:

- Increasing the number of police force.

- Coarsening penal sentencing.

- Increasing the number of the prisoners.

Regarding the issues to respond to juvenile delinquency, at first hand, is the radical response equalizing "the system of effective sentencing" with the "system of heavy and penalizing convictions". Alongside the just asserted "radical" response, have also been proposed, continuously, more moderates responses that can be classified as "traditional". These support the thought to coarsen sentencing system, within constitutional provisions, with measures that should be used in a continuous way to fight criminality such as the increase in the number of the police force, strengthening and coarsening convictions, and increasing the number of prisoners. The citizens also require the previously mentioned responses; however, they do not constitute the most effective means, neither to lower criminality indicators nor to resolve conflicts provoked by the criminal acts.

Contrary to the "radical" and "conservative" responses, there are a wide range of recommendations and directives, worked out by professional sectors that are directly linked with the treatment of minors in risk ${ }^{34}$. Part of them is criminologists, lawyers, psychologists, sociologists, social workers, etc, which aim to resolve the conflicts incited by juvenile delinquency, mitigate any kinds of problems as well as treat and direct minors. All these should be realized within the constitutional order and by respecting human rights.

These recommendations have been compiled based on the directives provided by the United Nations and which have been summarized in the following international acts 35 :

* United Nations Guidelines for the Prevention of Juvenile Delinquency (The Riyadh Guidelines approved by the General Assembly of the United Nations with Resolution 4/12.)

* United Nations Rules for the Protection of Juveniles Deprived of Liberty.

* United Nations Minimum Rules for the Administration of Juvenile Justice. (Beijing's Rules)

* United Nations Convention on the Rights of the Child, 20 November 1989).

Interventions to be undertaken both by communities and by the state should be alternated in order to determine the strategy for a common action. Interventions to be undertaken, basing on recommendations by international acts effective in this domain are:

a) Prevention instead of penalization. The best way to prevent juvenile delinquency is to disallow the nascence of new delinquents. In order to achieve that, many reliable programs of social, economic and educational assistance and employment should be applied.

b) Diminishing the use of traditional, common justice. Other measures and different ways should be applied for resolving problems the juvenile delinquency brings forth, before the intervention of the Court. The decrease into the use of the common justice system requires the diminution of state interventions, by increasing the intervention of the other social groups for resolving conflicts, suchlike family, the school, community, etc. Maximum decrease of stationing juveniles into the penitentiary institutions and allowing it solely in exclusive cases.

c) Elasticity in determining penal sentencing and other measures. By means of effective measures which can be

${ }^{34}$ Palomba, F.: "Il sistema del processo penale minorile", Giuffrè Editore, Milano, 2002, p. 45-52.

${ }^{35}$ Landrove Díaz, G.: "Derecho penal de menores", tirant lo blanch, Valencia, 2001, p. 113-128. 
alternated and determined in consistency with the minor's specific circumstances, the respective conditions, the improvements and the progress regarding the execution of the measures, there can be achieved a better individualization of the imposed measure, so that it suits to the significance of the case and the minor's needs.

d) All the rights entitled to adults by the law should also be applicable to the juvenile offenders.

e) Increase of professionalism and specialization of the police forces in the domains related to juveniles, alongside judges, prosecutors and lawyers. Improvement to the technical aspects of these professions will bring a greater effectiveness in the integration of the juvenile delinquency.

Deeper understanding and effectuation of these recommendations, by searching more alternatives that would be acceptable by parties in conflicts incited by juvenile delinquency, instead of punishing and sentencing juveniles, would bring effective responses to this problem which has reached to this scale of aggravation, requiring the motivation of all sectors involved in penal policies to establish proper responses and solutions to this phenomenon.

\section{References}

\section{Legal Acts}

Penal Code of the Republic of Albania of 1995;

Convention on the Rights of Child of 1989.

United Nations Minimum Rules for the Administration of Juvenile Justice. (Beijing's Rules)

United Nations Rules for the Protection of Juveniles Deprived of Liberty.

United Nations Guidelines for the Prevention of Juvenile Delinquency (The Riyadh Guidelines)

David, P.R.: "Sociología criminal juvenil", Depalma, Buenos Aires, 1979;

Elezi, E; Hysi, V.: "Politika Kriminale", Tiranë, 2006;

Garrido Genovés, V.: "Delincuencia juvenil", Alambra, Madrid, 1986;

Garrido Genovés, V.; Redondo Illescas, S.: "Manual de criminología aplicada", Ediciones Jurídicas Cuyo, Mendoza, 1997;

Group of Authors: "Lo sviluppo antisociale: dal bambino al giovane adulto. Una prospettiva evolutiva e psichiatrico-forense", Raffaello Cortina Editore,Milano, 2010;

Hajdari, A.: "Sistemi i drejtësisë për të mitur", Prishtinë, 2010;

Herrero Herrero, C.: "Criminología (parte general y especial)", Dykinson, Madrid, 1997;

Herrero Herrero, C.: "Tipologías de delitos y de delincuentes en la delincuencia juvenil actual. Perspectiva criminológica", in Actualidad Penal, No 41, 2002;

Herrero Herrero C.: "Delincuencia de menores. Tratamiento criminólogico y juridico", Dykinson, Madrid, 2008;

Izquierdo Moreno, C.: "Delincuencia juvenil en la sociedad de consumo", Mensajero, Bilbao, 1980;

Kaiser, G.: "Introducción a la criminología", Dykinson, Madrid, 1988;

Landrove Díaz, G.: "Derecho penal de menores", tirant lo blanch, Valencia, 2001;

Loeber, R., Farrington, D. P.: "From juvenile delinquency to adult crime. Criminal careers, Justice policy, and Prevention", Oxford University Press, New York, 2012;

López Rey, M.: "Criminología. Criminalidad y planificación de la política criminal", Madrid, 1978;

Montañés Rodríguez, J.; Bartolomé Gutiérrez, R.; Latorre Postigo, J.M.; Rechea Alberola, C.: "Delincuencia juvenil femenina y su comparación con la masculina", in their common study "Estudios de criminología II", Universidad de Castilla La Mancha, Cuenca, 1999;

Muçi, Sh.: "E drejta penale, Pjesa e Përgjithshme", Botimet Dudaj, Tiranë, 2007;

Núñez Paz, M.A.; Alonso Pérez, F.: "Nociones de criminología", Colex, Madrid, 2002;

Palomba, F.: "Il sistema del processo penale minorile", Giuffrè Editore, Milano, 2002;

Siegel, L. J, Welsh B. C.: "Juvenile delinquency. Theory, Practise and Law", 11th edition, Wadsworth, Cengage Learning, 2009, 2012;

Sutherland, E. H, Cressey, D. R.: "Criminologia", përkthim i Zanichetti Mario, Giuffrè Editore, Milano, 1996;

West, D.J.: "La delincuencia juvenil", Labor, Barcelona, 1957;

Vjetari Statistikor i Ministrisë së Drejtësisë së Republikës së Shqipërisë i vitit 2013.

Also the following webpages have been consulted during completion of the study:

http://www.parliament.vic.gov.au

http://www.drejtesia.gov.al 